\title{
Ozonated water in the post-harvest treatment of coffee fruits
}

\author{
Fernando J. B. Brandão ${ }^{1}$, Marco A. M. Biaggioni ${ }^{1}$, Felipe C. S. Sperotto ${ }^{1}$, \\ Erika Fujita ${ }^{2}$, Paula L. Santos ${ }^{3} \&$ Magnun A. P. da Silva $^{1}$ \\ ${ }^{1}$ Universidade Estadual Paulista “Júlio de Mesquita Filho"/Faculdade de Ciências Agronômicas/Departamento de Engenharia Rural. Botucatu, SP. E-mail:
fernandojbb@gmail.com (Corresponding author); biaggioni@fca.unesp.br; sperotto@hotmail.com; penariol@gmail.com
${ }^{2}$ Universidade Estadual Paulista “Júlio de Mesquita Filho"/Faculdade de Ciências Agronômicas/Departamento de Horticultura. Botucatu, SP. E-mail:
erikafujita79@hotmail.com
${ }^{3}$ Universidade Estadual Paulista “Júlio de Mesquita Filho"/Faculdade de Ciências Agronômicas/Departamento de Defesa Vegetal. Botucatu, SP. E-mail:
paulinha_leite_santos@hotmail.com
}

Key words:

Coffea arabica

fungi

ozone

beverage quality

\begin{abstract}
A B S T R A C T
Ozone is used in many countries for the treatment of effluents, becoming a viable alternative in sanitation of coffee wastewater. However, the strong ozone oxidation, responsible for its germicidal effect, can also compromise grain and beverage quality. The objective of this study was to evaluate the quality of Arabica coffee in different periods of treatment with ozonated water and its effect after drying. Coffee fruits were subjected to ozonation at regular intervals of $0,5,10,20$, and $30 \mathrm{~min}$, with continuous stirring promoted by a recirculating water system at constant rate of $1 \mathrm{ppm}$ of solubilized ozone. The design was completely randomized with five treatments and four replicates. After obtaining the data, the analysis of variance was performed and means were compared by Tukey test ( $p \leq 0.05)$. The results showed a partial reduction of fungi after washing with ozonated water, but the same effect was not observed after drying. For coffee quality analysis, the longest times of exposure to the solubilized gas in the water produced some negative results in electrical conductivity and total and reducing sugars. However, the sensory quality of the beverage was maintained.
\end{abstract}

\section{Palavras-chave: \\ Coffea arabica \\ fungos \\ ozônio \\ qualidade da bebida}

\section{Água ozonizada no tratamento pós-colheita dos frutos do café}

\section{R E S U M O}

O ozônio é utilizado em muitos países para o tratamento de efluentes tornando-se uma alternativa viável no saneamento da água residuária do café porém a forte oxidação do ozônio, responsável pelo seu efeito germicida, também pode comprometer a qualidade do grão e da bebida. Propôs-se, neste trabalho, avaliar a qualidade do café arábica em diferentes períodos de tratamento com água ozonizada e verificar seu efeito após a secagem. Os frutos de café foram submetidos durante 0, 5, 10, 20 e 30 min de ozonização, com agitação contínua promovida pelo sistema de recirculação da água em taxa constante de 1 ppm de ozônio solubilizado. O delineamento foi inteiramente casualizado com 5 tratamentos e 4 repetições. Após obtenção dos dados foi realizada a análise de variância e as médias comparadas pelo teste de Tukey $(\mathrm{p} \leq 0,05)$. Os resultados mostraram a redução parcial de fungos após a lavagem com água ozonizada, porém não foi verificado o mesmo efeito após a secagem. Para as análises de qualidade do café os maiores tempos de exposição ao gás solubilizado na água proporcionaram variações negativas na condutividade elétrica e nos açúcares totais e redutores; entretanto, a qualidade sensorial da bebida se manteve. 


\section{INTRODUCTION}

The coffee washing operation is basically a separation of the fruit in two batches: cherry and green, a denser fruit, and float, a less dense fruit, based on bulk density difference (Borém et al., 2008).

After performing the coffee washing, fruit drying is considered one of the critical points in the quality of the final product. This is because some fungi species may associate with the grains and cause undesirable post-harvest changes (Ferreira et al., 2011). According to Silva et al. (2013) and Iamanaka (2014), the most common fungi that cause deterioration of the grains are Aspergillus species, Cladosporium spp. (at least two species), Fusarium spp. (at least six species), Phomaherbarium and the Penicillium genus.

The great advantage of its use, in relation to other sanitizing agents, is that ozone acts directly in microorganism cell walls, prevents the recovery of microorganisms after the attack and does not leave residual chemicals in the food (Chiattone et al., 2008).

The treatment with ozone at low doses may not be effective in the decontamination of the grains. At high dosages, ozone can promote the oxidation and deterioration of chemical constituents present in the grains, such as starch loss, lipid oxidation, protein modification, discoloration or loss of seed germination (Isikber \& Athanassiou, 2014).

Some studies have sought to correlate the maintenance of chemical and physico-chemical quality of coffee beans, along with the sensory quality of the beverage during post-harvest of the product (Borém et al., 2008). Among these highlights, there is the analytical quantification of sugar, phenolic compounds, electrical conductivity, potassium leaching and proof of cup (Saath et al., 2014).

The objective in this study was to evaluate the quality of Arabica coffee in different periods of treatment with ozonated water and its effect after drying.

\section{Material AND Methods}

The experiment used about $480 \mathrm{~L}$ of farm coffee, from the Catuai Red variety. After harvesting, the grains underwent the separation process of green coffee, cherry and floats on the farm, through a washer.

The fruits with approximately $60 \%$ moisture content (wet basis, w.b.) were taken to the Biosciences Institute at the Department of Chemistry and Biochemistry of UNESPBotucatu, for ozonation. Before each treatment, one ozonation was performed for $10 \mathrm{~min}$, in order to saturate the ozone into the water and keep it constant at $1 \mathrm{ppm}$.

The treatments used approximately $2 \mathrm{~kg}$ of coffee for each sample, placed on mesh plastic bags with $0.015 \times 0.05 \mathrm{~m}$ mesh, which was placed in the ozonator tank with a volume of 0.105 $\mathrm{m}^{3}$ and, sequentially, the coffee was subjected to different treatment periods $(0,5,10,20$, and $30 \mathrm{~min})$. The device does not allow varying the concentration of $1 \mathrm{ppm}$; thus, the treatments were chosen with maximum of $30 \mathrm{~min}$ to simulate field conditions.

Immediately after the ozonation, the first fungal count was performed, in order to verify the potential of the gas in reducing fungi in coffee fruits. Then, the coffee was taken for drying in suspended stands simulating the drying terraces to reach approximately $12 \%$ moisture content (w.b.).The tickler of the grains was performed three times a day with the use of gloves by treatment, avoiding contamination between different times.

The drying air remained at $70.2 \%$ and $16.58{ }^{\circ} \mathrm{C}$ of relative humidity and average temperature, respectively, enabling the drying of coffee fruits in 10 days.

After drying, fungal count and coffee quality analysis were performed at the Laboratory of Fruit and Vegetable at the Faculty of Agricultural Sciences - FCA, UNESP.

An ozone generator (Degradatox/OZ Engineering) was used containing a centrifugal motor with water recirculation to perform ozone homogenization in the tank, with dimensions of $0.46 \times 0.53 \times 0.80 \mathrm{~m}$ (height $\times$ length $\times$ width), as described in Figure 1.

During the experiment, fractions of $50 \mathrm{~mL}$ of water were collected and analyzed for the amount of ozone solubilized in the tank, using digital ozone meter Chemetrics, a brand that uses the principle of spectrophotometry.

The fungal count was performed by the plating method in Gerboxes, using a blotter paper moistened with distilled water. Approximately, 12 grains from each sample were incubated and placed in a BOD (Biochemical Oxygen Demand) incubator at the temperature of $25^{\circ} \mathrm{C}$ for seven days. After the specified period, the plates were examined under a stereomicroscope to identify the toxigenic fungi (Brasil, 2009).

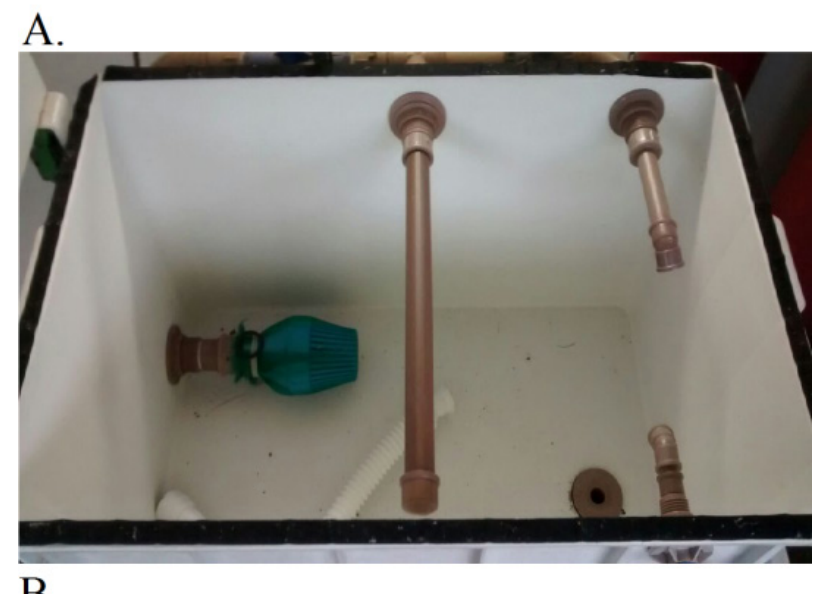

B.



Figure 1. Inside view of the ozonator tank and water circulation system (A). External view of the ozone generator and ozonator tank used in the experiment (B) 
Grain quality was analyzed based on fatty acidity, electrical conductivity, potassium leaching, total and reducing sugars, phenolic compounds and sensory analysis.

The evaluation of fatty acidity was performed according to procedures determined by AACC (1995).

The electrical conductivity of raw grains was determined by adapting the methodology proposed by Krzyzanowsky et al. (1991). After determining the electrical conductivity results, aliquots were taken from each sample of solutions for determining the amount of potassium ions leached in the raw grains. Following the method proposed by Prete (1992), this determination is made with the aid of a flame photometer.

Total and reducing sugars were obtained by the SomogyNelson method, described in Somogy (1945), and determined by the SOMOGY technique. The contents of total and reducing sugars were determined by spectrophotometry at specific wavelengths of $490 \mathrm{~nm}$ and $520 \mathrm{~nm}$, respectively.

The determination of total phenolic compounds of coffee was performed according to the method of Folin Ciocalteau, described by Singleton et al. (1999).

Sensory analysis of the beverage was determined at the Agronomic Institute of Campinas (IAC) and the coffee was rated based on numeric criteria, such as flavor and aroma. Scores were used in determined ranges to characterize the different beverage groups. The values used were in accordance with the classification described by SSCA (2012).

In the fungal count process, it was decided to analyze the percentage results.

The design was completely randomized with five treatments and four replicates. After obtaining the data, the analysis of variance was performed and means were compared by Tukey test $(p \leq 0.05)$. Statistical analyses were conducted using the Minitab software (Version 16).

\section{Results AND Discussion}

The percentage values of grains contaminated with fungi in coconut coffee samples, soon after ozonation, show that the ozone application is effective in controlling the fungus of the genus Fusarium spp., reducing by about $95 \%$ the presence of this species in treatment with $30 \mathrm{~min}$ exposure to ozonated water.

There are reports of this genus as a contaminant of food, presenting species of mycotoxins producers (Schollenberger et al., 2005). However, there was no reduction in fungi of the genus Colletrotrichum spp. (Table 1).

Fusarium spp. is less resistant than other species of fungi to ozone treatment. According to White et al. (2013), a treatment with ozone at a concentration of $500 \mathrm{ppm}$ reduced $76 \%$ of the population of Fusarium in corn grain, while there was no significant reduction in the presence of Cladosporium spp.

Mylona et al. (2014) also found a reduction of Fusarium spp. in corn; Kottapalli et al. (2005) found that the ozone treatment may reduce the growth of Fusarium spp.by $24 \%$ after $15 \mathrm{~min}$ of gas exposure at concentrations of 11 and 26 $\mathrm{mg} \mathrm{g}^{-1}$ in barley malt.

After drying, it was noted that the treatment with ozonated water was not able to maintain the reduced levels of fungi in coffee fruits. There was a prevalence of fungi of the genus Colletrotrichum spp. and Clasdosporium spp. and genus Rhizotopus spp. in lowest percentages.

During the coffee washing, it was found that ozone reduced the fungal infestation potential in fruits, which could represent an advantage in subsequent processing steps, although there is no residual power in the ozone. However, this initial sanitization has not translated into a different control for the next steps, showing no significant differences for infestation in the tested treatments.

Ozone showed results similar to those of other sanitizers used in coffee, such as benzalkonium chloride (Favarin et al., 2004) and sodium hypochlorite solution at $0.05 \%$ (Schmidt et al., 2010). Both authors found that, after drying on terraces, no significant differences in the control of fungi between treatments with or without sterilization.

In the grain quality analysis, the free fatty acid content of the grain did not change significantly between the ozonation times, as seen in Table 2, as confirmed by Li et al. (2013) and Chen et al. (2014). This result indicates that alterations in other components may have induced a protective effect on the amount of oil present in the coffee grain.

The increased exposure of the fruit to the ozonated water caused the rise in electrical conductivity, wherein the $30 \mathrm{~min}$ treatment showed the higher electrical conductivity values according to Table 2, which may be due to oxidation caused by ozone in the cell membrane providing the increased permeability of the wall and, consequently, higher electrolyte leaching in the tissue (Aday \& Caner, 2014). The increase in electrical conductivity was a more sensitive reaction to membrane damage in comparison to the fatty acid, and it is possible to observe the effect of the ozonation in longer exposure times, unlike the fatty acid analysis.

The potassium leaching did not show any differences between the washing times with ozonated water, as seen in Table 2. It was expected that the potassium leaching followed the same trend of the electrical conductivity, by increasing its

Table 1. Percentage values of colonization by fungi in coffee after ozonation and drying

\begin{tabular}{|c|c|c|c|c|c|c|}
\hline Moments & Treatments/times (min) & Fusarium spp. & Colletotrichum spp. & Cladosporium spp. & Rhizotopus spp. & Aspergillus spp. \\
\hline \multirow{4}{*}{ After ozonation } & 0 & 72.2 & 80.5 & - & - & - \\
\hline & 5 & 30.6 & 94.4 & - & - & - \\
\hline & 10 & 44.4 & 94.4 & - & - & - \\
\hline & 30 & 5.5 & 97.2 & - & - & - \\
\hline \multirow{4}{*}{ After drying } & 0 & - & 94.4 & 77.7 & - & - \\
\hline & 5 & - & 100 & 80.5 & 8.33 & - \\
\hline & 20 & - & 100 & 83.3 & 33.3 & 2.7 \\
\hline & 30 & - & 100 & 80.5 & - & - \\
\hline
\end{tabular}


Table 2. Chemical and biochemical characteristics of coffee submitted to different ozonation times after drying

\begin{tabular}{|c|c|c|c|c|c|c|c|}
\hline $\begin{array}{l}\text { Ozonation } \\
\text { times (min) }\end{array}$ & $\begin{array}{c}\text { Fatty acid } \\
\mathrm{mL} 100 \mathrm{~g}^{-1} \mathrm{DM}\end{array}$ & $\begin{array}{l}\text { Electrical } \\
\text { conductivity } \\
\mu \mathrm{S} \mathrm{cm}^{-1} \mathrm{~g}^{-1}\end{array}$ & $\begin{array}{l}\text { Potassium } \\
\text { leaching } \\
\mathrm{g} \mathrm{kg}^{-1}\end{array}$ & $\begin{array}{c}\text { Total } \\
\text { sugars } \\
\%\end{array}$ & $\begin{array}{c}\text { Reducing } \\
\text { sugars } \\
\%\end{array}$ & 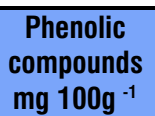 & $\begin{array}{c}\text { Sensory } \\
\text { evaluation }\end{array}$ \\
\hline 0 & $14.56 \mathrm{a}$ & $35.99 a^{3}$ & $1.57 \mathrm{a}$ & $9.07 \mathrm{a}$ & $1.41 \mathrm{a}$ & $39.44 \mathrm{a}$ & $76.50 \mathrm{a}$ \\
\hline 5 & $14.44 \mathrm{a}$ & $39.57 a b$ & $1.86 \mathrm{a}$ & $8.23 \mathrm{ab}$ & $1.27 \mathrm{ab}$ & $37.44 \mathrm{a}$ & $77.75 \mathrm{a}$ \\
\hline 10 & $13.69 \mathrm{a}$ & $34.98 \mathrm{a}$ & $1.74 \mathrm{a}$ & $8.05 \mathrm{~b}$ & $1.13 \mathrm{~b}$ & $36.31 \mathrm{a}$ & $76.62 \mathrm{a}$ \\
\hline 20 & $14.13 \mathrm{a}$ & $40.32 \mathrm{ab}$ & $1.51 \mathrm{a}$ & $7.56 \mathrm{~b}$ & $1.27 \mathrm{ab}$ & $37.90 \mathrm{a}$ & $77.12 \mathrm{a}$ \\
\hline 30 & $15.00 \mathrm{a}$ & $46.98 \mathrm{~b}$ & $2.04 \mathrm{a}$ & $7.48 \mathrm{~b}$ & $1.12 b$ & $36.09 \mathrm{a}$ & $78.06 \mathrm{a}$ \\
\hline CV (\%) & 8.59 & 11.72 & 33.17 & 4.96 & 9.94 & 12.03 & 1.41 \\
\hline
\end{tabular}

Means followed by the same letter in the column do not differ by Tukey test $(p \leq 0.05)$

level with an increase in exposure to ozonated water because the coffee grains are with about $40 \%$ of potassium ions. Thus, it is likely that other ions with lower expression in coffee were leached, such as magnesium, rubidium, copper, manganese, calcium and iron, among others, which are also present in coffee (Illy \& Viani, 1996). As the data found in Table 2, there was a reduction in the values of total and reducing sugars with an increased ozonation time. The treatment with $30 \mathrm{~min}$ had the lowest concentrations of sugars. Possibly, the application of ozonated water may have oxidized the cell wall of the fruit and allowed the loss of reducing and total sugars through the membrane.

Probably, the reduction in the content of total and reducing sugars in the fruit mucilage due to oxidation caused by ozone did not allow the sugars present in the mucilage to be fully transmitted to grain during drying.

The reduction of total sugars was also observed by Nascimento et al. (2008) in treatments with ozone in pulped coffees, and Vorne et al. (2012), who found significant decrease in reducing sugars (glucose and fructose) in potato tubers with increasing ozone exposure.

There was no change in the content of phenolic compounds, as described in Table 2. It was expected that the ozone application could result in an increase in the content of these phenols because a reaction of defense mechanisms of plants against the action of cell damage enabled the polyphenol formation, as described by (Sautter et al., 2011; Ali et al., 2014, Glowacz et al., 2015). It is likely that the ozone dose applied was insufficient to promote an increase in polyphenols due to the deterioration in the cell membrane. Another hypothesis is that the mucilage of the fruits protected the grain from the ozone action, with no observed effect on the production of polyphenols after drying.

In the sensory evaluation of the beverage, according to Table 2, the grains did not suffer noticeable changes between the treatments and the values that remained near 77 of the beverage quality, namely of hard beverage coffees, are considered within the specialty coffees as an average standard rating (SCAA, 2012).

In treatments with coffee, Nascimento et al. (2008) and Armstrong et al. (2008) did not observe reduction in sensory quality of the beverage during use of ozone.

\section{Conclusions}

1. The treatment with ozone under the conditions of this experiment reduces the fungal contamination of fruit only during the washing process.
2. Ozone oxidation promoted an increased electrical conductivity and decreased total and reducing sugars, and did not change significantly leaching potassium, phenolic compounds and fatty acids.

3. The sanitization with ozone did not affect the sensory quality of the beverage, maintaining the standard coffee.

4. The ozonation did not control fungal reinfestation after drying; in spite of that, this process can be investigated for the reduction in the pollutant load of the washing water in coffee farms.

\section{Literature Cited}

AACC - American Association of Cereal Chemists. Methods 02- 02A: Fat acidity: Rapid method, for grain. In: Approved methods of the American Association of the Cereal Chemists. Saint Paul: AACC, v.1, 1995. 5p.

Aday, M. S.; Caner, C. Individual and combined effects of ultrasound, ozone and chlorine dioxide on strawberry storage life. LWT - Food Science and Technology, v.57, p.344-351, 2014.

Ali, A.; Ong, M. K.; Forney, C. F. Effect of ozone pre-conditioning on quality and antioxidant capacity of papaya fruit during ambient storage. Food Chemistry, v.142, p.19-26, 2014. http://dx.doi. org/10.1016/j.foodchem.2013.07.039

Armstrong, J. W.; Follett, P.; Brown, S. A.; Leesch, J. G.; Tebbets, J. S.; Smilanick, J.; Streett, D.; Portillo, M.; McHugh, T. H. Ozone fumigation to control quarantine pests in green coffee. In: Annual International Research Conference on Methyl Bromide Alternatives and Emissions Reductions. Orlando. Proceedings... Orlando, 2008.p.75-76.

Borém, F. M.; Coradi, P. C.; Saath, R.; Oliveira, J. M. Qualidade do café natural e despolpado após secagem em terreiro e com altas temperaturas. Ciência e Agrotecnologia, v.32, p.1609-1615, 2008. http://dx.doi.org/10.1590/S1413-70542008000500038

Brasil. Ministério da Agricultura, Pecuária e Desenvolvimento. Regras para análise de sementes. Brasília: Secretaria de Defesa Agropecuária, 2009. p.335-340.

Chen, R.; Ma, F.; Li, P. W.; Zhang, W.; Ding, X. X.; Zhang, Q.; Li, M.; Wang, Y. R.; Xu, B. C. Effect of ozone on aflatoxins detoxification and nutritional quality of peanuts. Food Chemistry, v.146, p.284288, 2014. http://dx.doi.org/10.1016/j.foodchem.2013.09.059

Chiattone, P. V.; Torres, L. M.; Zambiazi, R. C. Aplicação do ozônio na indústria de alimentos. Alimentos e Nutrição, v.19, p.341-349, 2008.

Favarin, J. L.; Villela, A. L. G.; Moraes, M. H. D.; Chamma, H. M. C. P.; Costa, J. D.; Dourado Neto, D. Qualidade da bebida de café de frutos cereja submetido a diferentes manejos pós colheita. Pesquisa Agropecuária Brasileira, v.39, p.187-192, 2004. http:// dx.doi.org/10.1590/S0100-204X2004000200013 
Ferreira, G. F. P.; Novaes, Q. S.; Batista, L. R.; Souza, S. E.; Azevedo, G. B.; Silva, D. M. Fungos associados a grãos de café (Coffea arabica L.) beneficiados no sudoeste da Bahia. Summa Phytopathologica, v.37, p.98-102, 2011. http://dx.doi.org/10.1590/ S0100-54052011000300003

Glowacz, M.; Colgan, R.; Rees, D. Influence of continuous exposure to gaseous ozone on the quality of red bell peppers, cucumbers and zucchini. Postharvest Biology and Technology, v.99, p.1-8, 2015. http://dx.doi.org/10.1016/j.postharvbio.2014.06.015

Iamanaka, B. T. The mycobiota of coffee beans and its influence on the coffee beverage. Food Research International, v.62, p.353-358, 2014. http://dx.doi.org/10.1016/j.foodres.2014.02.033

Illy, A.; Viani, R. Espresso coffee: The chemistry of quality. 2.ed. San Diego: Academic Press, 1996. 253p.

Isikber, A. A.; Athanassiou, C. G. The use of ozone gas for the control of insects and micro-organisms in stored products. Journal of Stored Products Research, v.58, p.1-7, 2014.

Kottapalli, B.; Wolf-Hall, C. E.; Schwarz, P. Evaluation of gaseous ozone and hydrogen peroxide treatments for reducing Fusarium survival in malting barley. Journal of Food Protection, v.68, p.1236-1240, 2005.

Krzyzanowsky, F. C.; França Neto, J. B.; Henning, A. A. Relatos dos testes de vigor disponíveis as grandes culturas. Informativo ABRATES, v.1, p.15-50, 1991.

Li, M.; Peng, J.; Zhu, K. X.; Guo, X. N.; Zhang, M.; Peng, W.; Zhou, H. M. Delineating the microbial and physical-chemical changes during storage of ozone treated wheat flour. Innovative Food Science and Emerging Technologies, v.20, p.223-229, 2013. http:// dx.doi.org/10.1016/j.ifset.2013.06.004

Mylona. K.; Kogkaki, E.; Sulyok, M.; Magan, N. Efficacy of gaseous ozone treatment on spore germination, growth and fumonisin production by Fusarium verticillioides in vitro and in situ in maize. Journal of Stored Products Research, v.59, p.178-184, 2014. http:// dx.doi.org/10.1016/j.jspr.2014.08.001

Nascimento, L. C.; Lima, L. C. O.; Picolli, R. H.; Fiorini, J. E.; Duarte, S. M. S.; Silva, J. M. S. F.; Oliveira, N. M. S.; Veiga, S. M. O. Ozônio e ultra-som: Processos alternativos para o tratamento do café despolpado. Ciência e Tecnologia de Alimentos, v.28, p.282-294, 2008. http://dx.doi.org/10.1590/S0101-20612008000200004

Prete, C. E. C. Condutividade elétrica do exsudato de grãos de café (Coffea arabica L.) e sua relação com a qualidade da bebida. Piracicaba: Escola Superior de Agricultura "Luiz de Queiroz", 1992. 125p. Dissertação Mestrado
Saath, R.; Broetto, F.; Biaggioni, M. A. M.; Borém, F. M.; Rosa, S. D. V. F.; Taveira, J. H. S. Activity of some isoenzymatic systems in stored coffee grains. Ciência e Agrotecnologia, v.38, p.15-24, 2014. http://dx.doi.org/10.1590/S1413-70542014000100002

Sautter, C. K.; Brackman, A.; Anese, R. O.; Weber, A.; Rizatti, M. R.; Pavanello, E. P. Controle da podridão-parda e características físico-químicas de pêssegos 'Magnum' submetidos a tratamentos pós-colheita com elicitores abióticos. Revista Ceres, v.58, p.172177, 2011. http://dx.doi.org/10.1590/s0034-737x2011000200007

SCAA - Specialty Coffee Association of America. <http://www.scaa. org>. 10 Nov. 2013.

Schmidt, C. A. P.; Miglioranza, E.; Homechin, M. Microflora associada aos grãos de café em coco beneficiados e produzidos no Paraná. Revista Brasileira de Tecnologia Agroindustrial, v.4, p.10-18, 2010. http://dx.doi.org/10.3895/S1981-36862010000100002

Schollenberger, M.; Müller, H. M.; Rüfle, M.; Suchy, S.; Planck, S.; Drochner, W. Survey of Fusarium toxins in foodstuffs of plant origin marketed in Germany. International Journal of Food Microbiology, v.97, p.317-326, 2005. http://dx.doi.org/10.1016/j. ijfoodmicro.2004.05.001

Silva, C. F.; Vilela, D. M.; Cordeiro, C. S.; Duarte, W. F.; Dias, D. R.; Schawn, R. F. Evaluation of a potential starter culture for enhance quality of coffee fermentation. World Journal of Microbiology and Biotechnology, v.29, p.235-247, 2013. http://dx.doi.org/10.1007/ s11274-012-1175-2

Singleton, V. L.; Orthofer, R.; Lamuela, R. M. Analysis of total phenol and other oxidation subtrates and antioxidants by means of folinciocauteau reagent. Methods of Enzymology, v.299, p.152-178, 1999. http://dx.doi.org/10.1016/S0076-6879(99)99017-1

Somogy, M. Determination of blooded sugar. Journal Biologic Chemical, v.160, p.69-73, 1945.

Vorne, V.; Ojanpera, K.; Temmerman, L.; Bindi, M.; Högy, P.; Jones, M. B.; Lawson, T.; Persson, K. Effects of elevated carbon dioxide and ozone on potato tuber quality in the European multiple-site experiment 'CHIP project'. European Journal Agronomy, v.17, p.369-381, 2012. http://dx.doi.org/10.1016/S1161-0301(02)000722

White, S. D.; Murphy, P. T.; Leandro, L. F.; Bern, C. J.; Beattie, S. E.; Leeuwen, J. H. Mycoflora of high-moisture maize treated with ozone. Journal of Stored Products Research, v.55, p.84-89, 2013. http://dx.doi.org/10.1016/j.jspr.2013.08.006 